\title{
ANALYSIS OF THE EXPERIENCE OF INDIVIDUALS WITH DISABILITY WITH SELECTED ASPECTS RELATED TO MONO-SKIING
}

\author{
Ivan Růžička ${ }^{1}$, Kamila Růžičková ${ }^{2}$, Lucie Francová ${ }^{1}$, Dita Culková ${ }^{1}$ \\ ${ }^{1}$ Department of Physical Education and Sports, Faculty of Education, University of Hradec Králové, Rokitanského \\ 62/26, 50003 Hradec Králové (CZECH REPUBLIC) \\ ${ }^{2}$ Institute of Primary, Pre-primary and Special Education, Faculty of Education, University of Hradec Králové, \\ Rokitanského 62/26, 50003 Hradec Králové (CZECH REPUBLIC)
}

Eduport 5 (1) - Reviewed Papers

DOI: 10.21062/edp.2021.006

\begin{abstract}
Physical activities for individuals with disability contribute to improving motor skills and positively affect psychosocial areas of life. The mono-ski winter activity is currently experiencing a great development in our country. The aim of the study was to analyze the experiences of individuals with disability with selected aspects related to mono-skiing through the processing of quantitative data obtained via a questionnaire survey. The research sample consisted of 60 persons - participants of mono-ski courses at the Centre for Disabled Skiers in Janské Lázně. The results of the survey show that $76.6 \%$ of the respondents consider mono-skiing to be an important part of their lives. The three key benefits cited by respondents were 1 ) increased joy of life and the opportunity to have fun, 2) diversified life and feeling of excitement, and 3) establishing warm relationships with others. In addition to the above values, the main reasons leading to mono-skiing included enhancing psychological stability as a means of improving mental health. The study results also show that of the target group of post-injury individuals (21 individuals), $81 \%$ returned to skiing thanks to mono-skiing and the activity helped to maintain the level of their previous life. The results suggest that monoskiing contributes not only to the possibility of carrying out one's own physical activity, but also to improving psychological health, contact with others, and dedication to skiing even in the post-injury state. We present the findings of the analysis as initial outputs of a planned larger study that will aim to evaluate the impact of mono-skiing on the quality of life in individuals with disability involved in this activity.
\end{abstract}

Key words: Physical activity, individuals with disability, skiing, mono-ski.

\section{INTRODUCTION}

Physical activity is an important part of life in the contemporary population, of all ages, levels and areas [10]. The inherent importance of regular exercise extends to individuals with disability, where engaging in appropriate activities can have other significant benefits compared to the able-bodied population [3]. When focusing on active movement for individuals with disability, different, but in practice often interrelated goals can be pursued: developing basic movement abilities and skills, seeking positive experiences, shaping psychological characteristics, overcoming obstacles or social barriers, and others [11]. According to the WHO, the four basic dimensions of human quality of life include physical health, mental health, social climate and environment [46]. Meeting needs in these areas aims at satisfaction, comfort, well-being and security of life even in conditions of serious and permanent damage to health or organism [18]. Efforts to create a healthy lifestyle for individuals with disability, in which movement has an irreplaceable value, affect the overall level of positive 
experience of life [41], with regular physical activity positively affecting the physical, psychological and social domains [29].

\section{The significance of exercise for individuals with disability}

Appropriate physical activity ensures that individuals with disability improve their motor skills, posture, spatial orientation and overall coordination. For individuals with physical disability, the health significance of exercise is seen in increasing joint range and strength levels, compensating for muscle imbalances, reducing muscle contractures and compensating for unilateral loading [42]. Appropriate and adequate physical activity can be considered as an effective remedy against muscle atrophy. It maintains and develops the overall physical fitness of individuals with disability. This is manifested primarily by the development of muscular strength and endurance performance, which are important components of complex skills that enable individuals with disability to cope with the tasks of daily life $[2,17]$.

Physical activity positively influences the overall self-concept of a person by increasing selfconfidence, independence, sense of self-worth, awareness of self-discipline and self-control, and brings subjective feelings of health, strength, and energy [2]. The formation of psychological qualities of an individual, such as free effort, ability to concentrate, manage emotions, adaptation and cooperation, coping with conflict situations, compensating for feelings of inferiority and coping with stress [4]. The experience accompanying physical activity leads to an increase in self-esteem and selfconfidence, pride after exercise, improved self-control, awareness of health benefits, and success in terms of achievement and mastery of the physical task [37]. These values are very attenuated in an individual with disability and can be more easily fulfilled through physical activity. Also, the importance of re-engaging in physical activity practiced prior to the acquired disability as a suitable alternative and the benefits of such a return to quality of life are emphasized by Williams, Smith and Papathomas [47], adding that this can significantly aid in disability acceptance. The impact on perceptions, self-efficacy in relation to physical activity and sport is also confirmed by Shapiro and Ulrich [38] based on their research. Lahtinen, Rintala and Malin [24], summarize that involvement in physical activities leads to improvement, visibility, recognition and thus a higher level of social status, which significantly affects the psychological state of the individual. A link is established between the psyche and the social domain.

Social barriers are also overcome during physical activities. An individual with disability accepts their social roles, establishes contacts and new friendships with individuals with disability or healthy individuals [3]. Through these relationships, the individual becomes involved in other social activities and social isolation is reduced. Physical education and sport as a social phenomenon has significant inclusive potential [26]. The results of Sale [36] demonstrate that involvement in physical activities positively influences full participation in society, strengthens family integrity and significantly expands the scope of social contacts. This is a significant and sought-after benefit of physical activity for individuals with disability [7] in the context of the so-called inclusion - the highest degree of socialization of an individual, i.e. a kind of merging with the environment, equal inclusion in society [45]. In principle, it is about connecting a group of individuals with disability with a group of healthy people, between which a certain segregation boundary is broken down, while the degree of integration is conditioned by the degree of equivalence of the individual with disability [35].

\section{Physical activity for individuals with physical disability}

Physical disability causes some limitation of independence, affecting mobility and work activity [43]. Today's society offers individuals with disability many means to significantly eliminate their disadvantages and live a full life [9]. One of the significant causes limiting an individual's ability to move is lower limb amputation. Current technological advances providing modern compensatory aids contribute significantly to the realization of a full life for wheelchair users and offer compensatory fulfillment of various aspects of the importance of physical education and sports [13, 
$40,11]$. Not only some summer but also winter physical activities such as sledge hockey or skiing are suitable for the mentioned mobility limitations [22, 20]. Nasuti and Temple [28] have shown that the risks of snow sports are no greater than in the general population, and have provided some evidence that skiing can positively affect self-esteem, self-concept, and fundamental motor function in individuals with physical disability.

\section{Downhill skiing for individuals with disability and the situation in the Czech Republic}

The mono-ski is a special sporting equipment that compensates for the disadvantages of skiers with physical disability - men and women with spinal cord lesions, spastics and people with lower and upper limb amputations, and allows them to join the skiing community. The choice of mono-ski is highly individual, it can also be made directly to the mono-skier's specifications. It consists of one regular ski, on which is fixed in a strong binding a load-bearing and very strong aluminium structure with a Kevlar or fibreglass shell in which the skier is seated, which also protects the lower limbs from injury and prevents them from getting cold. Active safety is supplemented within the shell by the use of an adjustable shock absorber and, according to the individual needs of the skier, by fixation belts that replace non-functioning muscles and keep the legs immobile in a position that prevents unwanted misalignment. [1]. The mono-ski design allows the shell to be lifted to a position suitable for boarding a chairlift, or it can be towed on an older POMA type lift or anchor using a towing device with a manual release lock at the end of the lift.

Kvasnička [23] states that downhill skiing on mono-ski is a young sport that has seen great development in recent years. Thanks to the technological maturity of compensatory aids, it can be practiced by individuals with severe physical or combined disability [34, 25, 15]. Petrofsky [33] demonstrated that mono-skiing correlates with high levels of satisfaction among mono-skiers, low levels of fear of falling and an increase in their quality of life. The first mono-ski designs were produced in Germany, followed by the USA and Canada. According to Hruša [14], the slow development was mainly related to the difficulty of accessibility of the equipment both in winter resorts (barrier-free access) and for the skiers themselves. Nowadays, mono-skiing is mainly implemented in the form of instructional courses, promotional events and some ski schools already offer individuals the necessary equipment and professional help. Mono-skiing is also practised as a performance sport platform, where it respects the rules of the Fédération Internationale de Ski (FIS), with some specific regulation of the sport for individuals with disability. In the context of international competitions for skiers with disability, competitors are divided into separate categories - standing and sitting skiers. Mono-skiing, designed for seated skiers, is also one of the Paralympic sports that are jointly umbrellaed by the International Paralympic Committee (IPC) [16], where alpine skiing has its own IPCAS (IPC alpine skiing) section.

In the Czech Republic, the public first encountered mono-ski in 1988 in Špindlerův Mlýn, where the National Championships for skiers with physical disability were held. Since 1992, wheelchair skiing has been developed at the Faculty of Physical Culture of Palacký University in Olomouc in the Centre of Applied Movement Activities and since 1994 at the Faculty of Physical Education and Sport of Charles University in Prague in the Centre of Sports Activities for the Disabled. The number of organisations and instructors involved in mono-skiing in the Czech Republic is gradually increasing, but the demand is still greater than the supply [20]. Fanatic and the Newman school have been organising Mono-ski Days in the Czech Republic for several years, in which the general public can experience the activity in the form of their own physical experience. The Sportability civic association offers a sophisticated program from beginner courses to training for athletes. The Paraple Centre runs several beginners' courses each year, focusing mainly on clients paralysed from spinal cord injuries and using bi-ski, kart-ski and dual-ski in addition to mono-ski in its activities. Several Czech entities such as Handy Club Ostrava, SKV Prague, MONOSKI Zlín, etc. organize ski lessons and are able to lend mono-ski to interested parties. 
Currently, the most important entity in the field of downhill skiing for individuals with physical disability is the non-profit organization with nationwide scope, the Centre for Handicapped Skiers $(\mathrm{CHL})$, based in Janské Lázně, which has been involved in skiing for individuals with disability since 2005 under the auspices of the Ski Association of the Czech Republic. It has continued its activities in the organization of individual instructional ski courses for wheelchair skiers organized since 1996. The activities of this public benefit organisation, based in world-famous mountain spas focused on the musculoskeletal system, are mainly aimed at skiing for individuals with severe physical disability, mainly young people and children after spinal injuries, as well as clients with congenital defects and people with the consequences of musculoskeletal disorders. According to Pavlasová [32], this is a unique Czech comprehensive project for individuals with physical disability, regardless of age. The association organizes mono-ski instructional courses with a special focus on the young post-injury generation of wheelchair users, organizes licensed volunteer training courses and training of performance skiers with physical disability under the guidance of experienced coaches. The CHL is currently the only organizer of domestic and international races organized in the Czech Republic under the auspices of the International Paralympic Committee. Over the last 16 years, $80 \%$ of Czech athletes have been through the $\mathrm{CHL}$ sports programme. However, during the pandemic government restrictions on SARS-CoV-2, the CHL only conducted its activities in the Austrian Alps, and only in a very limited performance mono-ski programme. The CHL acts as the Alpine Skiing Centre of the Czech Association of Athletes with Disability, the volume of $\mathrm{CHL}$ activities in the winter season $2017 / 2018$ (the last regular season before the pandemic restrictions related to Covid 19) amounted to 143 instructional and sports days attended by 124 skiers with physical and visual disability and over 150 volunteers. The total expenditure on the implementation of $\mathrm{CHL}$ programmes, mainly covered by sponsorship donations and regional institutions, was over 3.4 million CZK in the season [8]. With its wide range of activities, professional qualities, many years of experience and enthusiasm, the CHL has a significant positive impact on the process of coping with disability, participation in an active lifestyle and contributes to ensuring a better quality of life for individuals with physical disability in the Czech Republic.

\section{METHOD}

The aim of the study is to analyze the experiences of individuals with disability with selected aspects related to mono-skiing by processing quantitative data obtained through a questionnaire survey and thus to evaluate the benefits of mono-skiing in various areas.

The following study questions were formulated to meet the objective:

SO1: What motives led the respondents to engage in physical activity on the mono-ski?

SO2: What number of skiers return to skiing with a mono-ski after a disability (injury)?

SO3: What percentage of respondents rate mono-skiing as beneficial to their lives?

SO4: What specific benefits of mono-skiing did respondents identify as crucial?

\section{Participants}

The study was carried out in cooperation with the non-profit organization Center for Handicapped Skiers [1]. The study population consisted of 60 individuals with physical disability. The selection of respondents for the study population was casual, they were all active participants of mono-ski courses in Janské Lázně in the last regular season before the pandemic restrictions related to Covid 19. No respondent exercised the option to decline participation in the study.

36 men and 24 women with an average age of 26.19 years participated in the survey. The highest representation was 19 respondents aged 21-34 years (31.67\%) and out of which 14 were male and 5 were female, 15 respondents aged $16-20$ years $(25.00 \%)$ and out of which 7 were male and 8 were female and 11 respondents aged 35-45 years (18.33\%) and out of which 7 were male and 4 were 
female. Out of 60 respondents, 26 persons (43.33\%) were from the category of youth below 20 years. According to the type of disability, the study population consisted of persons with cerebral palsy (33 persons, which accounted for $55 \%$ of the respondents), spinal cord injury $(13,21.67 \%)$, spina bifida $(4,6.67 \%)$, amputation $(2,3.33 \%)$, as well as congenital muscular atrophy $(1,1.67 \%)$, combined disability (1) and other type of disability $(6,10 \%)$. In terms of cause of disability, $65.00 \%$ of respondents had a congenital defect (39 persons, 20 males and 19 females) and $35.00 \%$ had an acquired defect ( 21 persons after injury, 16 males and 5 females). Acquired defect was more frequently reported by males $(44.44 \%$ of total males) compared to females $(20.83 \%$ of female participants).

\section{Design}

The study methodology is based on an empirical scientific procedure using a quantitative approach based on the deductive process of a questionnaire survey. It was intended to obtain objective data and the resulting verifiable and comparable results, interpretations and answers to the formulated questions with the pronouncement of conclusions to substantiate the observed facts.

\section{Procedure}

Data collection took place in the 2018/19 winter season with the intention of continuing in 2019/20 and 2020/21, however, this did not materialise due to the onset of SARS-CoV-2/Covid-19 and the subsequent pandemic situation and the non-running of courses in these seasons. The venue for data collection was Janské Lázně, where residential facilities are provided directly at the CHL for course participants to participate in an educational or sporting mono-skiing programme. The planned continuation of data collection in the form of an intervention study and its processing using appropriate tools will further aim to evaluate the impact of mono-skiing on the quality of life in individuals with physical disability involved in this activity.

The preparation of the questionnaire survey was based on theoretical knowledge and personal experience; the questionnaire was of its own design due to the focus of the research and was administered to the respondents personally at the end of the course. Prior to the actual data collection, construct validation of the questionnaire in terms of future data validity was carried out to eliminate any potential shortcomings [5], not only by the research team in collaboration with the staff of the Centre for Disabled Skiers (CHL), but also on a sample of two individuals with physical disability who had previously attended mono-ski courses. Based on the feedback, the questionnaire version was modified and prepared for field use. The persons who participated in the process of questionnaire development and validation were not further included in the research sample.

A total of 65 questionnaires were distributed and 60 fully completed and evaluable questionnaires were returned. The return rate was therefore $92.3 \%$.

Data from the completed anonymous questionnaires were processed in Microsoft Excel 2015 and descriptive statistics and scaling were used to process the data. According to the type of questions and answers provided, the absolute frequency and percentage of facts were determined. For the evaluation of the benefits of mono-skiing ( $\mathrm{SO} 3$ ), we used the age distinction according to Wagner [45] with the interface of young and middle adulthood (35 years).

The results were tabulated and substantively interpreted.

\section{RESULTS}

We present the study data in the context of the study objective, the study questions asked and the aim of the study. To assess the experiences of individuals with disability with selected aspects related to mono-skiing, we have chosen a variety of areas that are proportionally related to the objective. Firstly, the motives for doing the activity and their preferences, then the issue of re-seeking the 
activity after an acquired disability (injury) as a tool to maintain the level of quality of previous life and the area of the benefits of mono-skiing for individuals with disability.

\section{S01: What motives led the respondents to engage in physical activity on the mono-ski?}

One of the sub-objectives of the study was to map the motives that lead the interviewed individuals with physical disability to practice downhill skiing on mono-ski and to determine their preference. The respondents were asked to assess the extent to which each of the pre-formulated reasons influenced their decision to take up mono-skiing. They expressed the weight of a given motive using a five-point scale, where a value of 1 represented a major reason, 2 a rather major reason, 3 I cannot decide, 4 a rather minor reason, and 5 no reason. The final ranking of the motives of the research population is based on the arithmetic means $(\mu)$ expressing the typical value of each outcome value supplemented by the absolute frequency of selection of the item $\left(X_{60}\right)$ from the total number of respondents.

Tab. 1 Motives leading to mono-skiing

\begin{tabular}{|l|l|c|c|}
\hline \multicolumn{2}{|c|}{ Motives leading to mono-skiing } & $\mu$ & $\mathrm{X}_{60}$ \\
\hline 1. & joy of movement, experience, fun & 1.22 & 51 \\
\hline 2. & meeting people, making friends & 1.78 & 28 \\
\hline 3. & mental balance, improvement of psyche & 2.23 & 21 \\
\hline 4. & self-realization & 2.40 & 15 \\
\hline 5. & improving fitness, health & 2.40 & 15 \\
\hline 6. & active lifestyle & 2.53 & 15 \\
\hline 7. & integration into society & 2.63 & 14 \\
\hline 8. & self-confidence and self-esteem & 2.95 & 7 \\
\hline 9. & appreciation from others & 3.20 & 9 \\
\hline 10. & striving to be equal to people without disability & 3.32 & 4 \\
\hline 11. & desire to compete & 3.87 & 5 \\
\hline 12. & effort to self-assertion & 3.88 & 5 \\
\hline
\end{tabular}

The results in Table 1 illustrate the preference of the motives of the respondents with physical disability. The most numerous motive for engaging in mono-skiing is the anticipated enjoyment of exercise, experience and fun. The second most frequent motive is the interest in meeting people and making friends, thus reflecting the need for socialization and inclusion among persons sharing the same interest. The third rank was occupied by the interest in one's own mental balance and improvement of the psyche using physical activity. Other more prominent motives included the pursuit of self-realization and then improving physical fitness and health. Surprisingly, this ranked relatively low in the tracking, followed by a preference for an active lifestyle. Motives such as appreciation from others, the desire to be equal to people without disability, the desire to compete and the desire for self-assertion ranked as significantly weak motives for the activity in question.

SO2: What number of skiers return to skiing with a mono-ski after a disability (injury)?

Tab. 2 Downhill skiing before the accident

\begin{tabular}{|r|c|c|c|}
\hline Were you skiing before your accident? & male & female & total \\
\hline yes & $14(87.50 \%)$ & $3(60.00 \%)$ & $17(80.95 \%)$ \\
\hline no & $2(12.50 \%)$ & $2(40.00 \%)$ & $4(19.05 \%)$ \\
\hline total & 16 & 5 & 21 \\
\hline
\end{tabular}


The data in Table 2 present the number and percentage of respondents who were actively involved in downhill skiing before the injury (acquired disability). The results demonstrate the relationship of the respondents' relationship to the activity in question (downhill skiing) before and after the injury. Out of 21 respondents with acquired disability, 17 responded that they had been involved in downhill skiing before the accident, which is $80.95 \%$ of the respondents. 4 respondents $(19.05 \%)$ had not been involved in downhill skiing in the past, mono-skiing was a new skiing experience for them.

The data on the number of those who return to downhill skiing in the form of mono-ski after an injury was then related to the area of fulfilment of expectations from switching to another form of skiing (mono-ski):

Tab. 3 Meeting expectations and previous skiing experience

\begin{tabular}{|r|r|c|c|c|}
\hline \multicolumn{6}{|c|}{ Meeting expectations and previous skiing experience } \\
\hline \multicolumn{2}{|c|}{} & \multicolumn{2}{c|}{ Were you skiing before your accident? } \\
\cline { 2 - 5 } & yes & no & \multicolumn{1}{c|}{ total } \\
\hline \multirow{2}{*}{$\begin{array}{r}\text { Did mono-skiing meet your } \\
\text { expectations? }\end{array}$} & $9(52.94 \%)$ & $4(100 \%)$ & $13(61.90 \%)$ \\
\cline { 2 - 5 } & rather yes & $8(47.06 \%)$ & 0 & $8(38.10 \%)$ \\
\cline { 2 - 5 } & cannot say & 0 & 0 & 0 \\
\cline { 2 - 5 } & rather no & 0 & 0 & 0 \\
\cline { 2 - 5 } & no & 0 & 0 & 0 \\
\cline { 2 - 5 } & total & $\mathbf{1 7}$ & $\mathbf{4}$ & $\mathbf{2 1}$ \\
\hline
\end{tabular}

From the data presented (number of respondents and percentages), it can be inferred that the interviewees who had experience of skiing before the injury and engaged in mono-ski activities after the injury expressed that mono-skiing had fulfilled their personal expectations. Thus, a total of $100 \%$ of the respondents interviewed expressed satisfaction and their expectations were met in this area. including those who only started skiing after their injury. Of the 21 positive responses, 13 responses were an unequivocal "yes", which is $61.90 \%$, and 8 responses were "rather yes", which is $38.10 \%$. No respondent expressed that mono-ski did not meet their expectations.

\section{SO3: What percentage of respondents rate mono-skiing as beneficial to their lives?}

For a richer illustration of the reality, we addressed the question of the evaluation of mono-skiing in terms of general benefits with gender and age distinctions.

Tab. 4 Evaluation of mono-skiing in terms of general benefits

\begin{tabular}{|r|c|c|c|c|c|}
\hline $\begin{array}{r}\text { Do you rate mono- } \\
\text { skiing as beneficial to } \\
\text { your life? }\end{array}$ & male & female & $\begin{array}{c}\text { under } 35 \\
\text { years }\end{array}$ & $\begin{array}{c}\text { above } 35 \\
\text { years }\end{array}$ & total \\
\hline yes & $25(69.44 \%)$ & $21(87.50 \%)$ & $35(77.78 \%)$ & $11(73.33 \%)$ & $46(76.67 \%)$ \\
\hline rather yes & $11(30.56 \%)$ & $3(12.50 \%)$ & $10(22.22 \%)$ & $4(26.67 \%)$ & $14(23.33 \%)$ \\
\hline cannot say & 0 & 0 & 0 & 0 & 0 \\
\hline rather no & 0 & 0 & 0 & 0 & 0 \\
\hline no & 0 & 0 & 0 & 0 & 0 \\
\hline total & $\mathbf{3 6}$ & $\mathbf{2 4}$ & $\mathbf{4 5}$ & $\mathbf{1 5}$ & $\mathbf{6 0}$ \\
\hline
\end{tabular}

The results in Table 4 show that more than two thirds of men (69.44\%) and even more than three quarters of women $(87.50 \%)$ answered that mono-skiing is clearly beneficial for their life, 11 men $(30.56 \%)$ and 3 women $(12.50 \%)$ are inclined to the positive influence ("rather yes"). In total, $100 \%$ of all respondents consider mono-skiing to be a beneficial part of their lives. 
In terms of the age distribution between the group of respondents from the younger generation (under 35 years) and the older generation (over 35 years) of respondents, we did not observe a significant disproportion in the results. When asked whether mono-skiing is beneficial for them, over three quarters of the younger respondents under 35 years of age (77.78\%) answered a clear "yes"; almost identical data were obtained for the older age group (73.33\%).

In general, $76.67 \%$ of the respondents expressed positive benefits of mono-skiing, regardless of gender or age, and $23.33 \%$ of the respondents were inclined to a positive evaluation, which makes a total of $100 \%$ of the study subjects.

\section{SO4: What specific benefits of mono-skiing did respondents identify as crucial?}

We asked a specific question: What is the order of importance in terms of the benefits of monoskiing for individuals with disability? Respondents were asked to rank the possible benefits of a given physical activity in order of personal importance, from 1 - most important to 5 - least important. It is therefore a value orientation representing a hierarchical ordering of the articulated benefits of mono-skiing to the lives of responents based on a fixed choice of options. The resulting ranking is constructed using arithmetic averages $(\mu)$ and supplemented with the absolute frequency of selection of the item $\left(\mathrm{X}_{60}\right)$.

Tab. 5 Specific benefits of mono-skiing for individuals with disability

\begin{tabular}{|l|l|c|c|}
\hline \multicolumn{2}{|c|}{ Specific benefits of mono-skiing } & $\mu$ & $\mathrm{X}_{60}$ \\
\hline 1. & fun and life enjoyment & 1,3 & 50 \\
\hline 2. & excitement, enriched life & 1.58 & 36 \\
\hline 3. & warm relationships with others & 1.92 & 30 \\
\hline 4. & self-realization & 2.35 & 19 \\
\hline 5. & sense of belonging & 2.53 & 15 \\
\hline 6. & feeling of success & 2.58 & 12 \\
\hline 7. & independence & 2.63 & 16 \\
\hline 8. & self-esteem & 2.77 & 9 \\
\hline 9. & being respected by others & 3.18 & 7 \\
\hline
\end{tabular}

The results of preferences in the area of benefits of mono-skiing show that the respondents of the research survey consider the most important benefit of mono-skiing to be the opportunity to have fun and increase the enjoyment of life, followed by the feelings of excitement accompanying this physical activity and thus diversifying life, and the possibility of establishing warm relationships with other people while doing it. The possibility of self-realization, a sense of belonging or a feeling of achievement were considered less important, while at the very end of the preferences the respondents placed independence, self-esteem and being respected by others.

\section{DISCUSSION}

The results presented in Table 1 map the motives leading to mono-skiing. They show that the most numerous motive for engaging in the activity is the anticipated enjoyment of exercise, experience and fun. This motive dominated the evaluation, with a significant majority $\left(X_{60}=51\right)$ citing it as their main reason. The second most common motive was the interest in meeting people and making friends $\left(X_{60}=28\right)$, indicating a strong need for individuals with disability to join a group of people with a common interest or to make new friends among individuals with similar disability. This corresponds with the findings of Sale [36], who documented that participation in physical activities brings the benefits mentioned above, soon after the acquired disability (after 4 years). A sense of belonging can be a significant factor in helping to return to a positive life. The third place was taken by an active interest in improved mental balance and overall improvement of the psyche $\left(\mathrm{X}_{60}=21\right)$. The result 
shows the need of individuals with disability to positively influence their psychological side of life. Physical activity not only increases the level of physical fitness of the body, but also brings a positive effect on the psychological side of the individual. This is highlighted by Nasuti and Temple [28] when they confirm that skiing positively affects self-esteem and self-worth in individuals with disability. According to Vágnerová (2012), disability is a psychological burden that a person must gradually learn to cope with and one of the appropriate ways is an active approach resulting from the belief that disability must be coped with in the mental plane. In this field, physical activities are an effective way to find reasons to overcome new challenges and experience strong emotions. This in turn is closely related to finding and maintaining optimism in life and has a significant impact on strengthening social relationships. As formulated by Kábele [19] by actively focusing on the areas of emotion management, adaptation to stress, coping with obstacles and overcoming social barriers, social role acceptance and networking within the intact population occurs.

Other preferred motives include the pursuit of self-realization, opportunities to engage in something that will bring another dimension and inner fulfilment to life. According to Maslow [27], it is the desire to satisfy one's needs, which may be physical, psychological or social, to discover and use one's own potential. The results suggest that the respondents with disability who have engaged in mono-skiing are among those who are interested in taking the next step in life, trying something new, overcoming obstacles, striving to achieve a goal associated with a new challenge and not just sticking to established ways of living. Perhaps it is disability that awakens the ambition to take responsibility for one's own life and its quality. In terms of the disability experienced, it is logical that other significant motives were the interest in improving physical fitness and health, and the preference for an active lifestyle. This agrees with van Koppenhagen et al.'s [41] finding that a wheelchair user's level of motor fitness corresponds with their life satisfaction. Conversely, motives such as appreciation from others, the desire to be equal to individuals without disability, the desire to compete and the effort to self-assertion ranked as significantly weak motives for the subject activity. The motive of self-promotion through sport, which might be expected to rank higher in preferences, ranked dead last in the ranking.

In our opinion, performance-oriented individuals who are already practicing or interested in performance mono-ski in the form of training and competitions will build more on this value. They may generally rank the motives for practicing mono-ski in a rather different order, where the latter items may realistically be among the main motives for the activity. The results are basically consistent with Hlaváčová's research [12] conducted among Czech sledge hockey players ( $n=15)$, i.e. individuals with physical disability actively involved in regular exercise also of a "winter nature". Consistently, the first place among the motives is clearly occupied by both groups by the experience, the joy of movement and the desire for fun. A difference in preference is found for the motive of improving physical fitness and health, which ranked as the second most important motive for engaging in physical activity in the 2006 survey. In our observation, it was ranked lower by respondents (up to $5^{\text {th }}$ place). Although Holm's study [13] demonstrates the importance of the position of physical activity for individuals with disability in health consolidation and we could therefore assume that this value remains at the forefront of motives, we believe that the reason for the lower ranking could be, for example, improved health care for individuals with disability or it could be due to the specificity of mono-ski as a seasonal physical activity.

Another area of study was to map the interest in downhill skiing among individuals with acquired disability who were engaged in this physical activity before the accident. We asked the question: What number of skiers return to mono-skiing after an injury? The results demonstrate the relationship of the interviewees' relationship to downhill skiing before and after the injury. Out of the total number of persons in the study population, 21 respondents had an acquired physical disability (Table 2). Of this group, 17 responded that they were involved in downhill skiing before the injury, which is $80.95 \%$ of the respondents. Table 3 further relates these data to the area of fulfilling 
expectations of switching to another form of skiing (mono-ski). Of the 21 positive responses, 13 responses were an unequivocal "yes" (61.90\%) and 8 responses were "rather yes" (38.10\%). It can be concluded that a full $100 \%$ of the respondents expressed that mono-skiing had fulfilled their personal expectations, whether they were those who had not been involved in skiing at all in the past or those who had already had experience of skiing before the accident and had become involved in the activity in a new, alternative way (mono-ski) after the accident. Thus, all respondents with acquired disability expressed clear satisfaction with downhill mono-skiing, this form of skiing met their expectations.

Later acquired disability represents a much greater psychological trauma, where the person is usually aware of what they may be losing by acquiring the disability. As Williams, Smith and Papathomas [47] point out, returning to activity with a suitable alternative can significantly help in terms of acceptance of the disability and the contribution to quality of life. This process is usually facilitated by previous skiing experience, positive transfer of some skills and the ability to perceive the specifics of the movement on snow. The application of some previous experience and skiing habits brings an advantage in the process of acquiring mono-ski technique. In practice, the persons in question usually adapt very well to the movement, become more independent on the slope and return to the previous positive feelings associated with the activity. However, the process can be disrupted by the markedly different nature of the movement on the ski slope. The results suggest that switching to a new movement technique does not act in a negative way and the alternative form of activity meets the needs of the implementers. Although, according to Opatřilová and Zámečníková [31], a common feature of individuals with physical disability is restricted movement, mono-skiing offers some compensation here. It is an extension of the possibilities for active life, moreover, in winter, an otherwise more demanding and poorer period for activities for individuals with physical disability. According to Jesenský [18], returning to a favourite activity practised before the acquisition of the impairment, in conjunction with the fulfilment of certain expectations, can become an important moment in the process of coming to terms with the impairment and moving towards life satisfaction, comfort and well-being.

The evaluation of mono-skiing in terms of general benefits is illustrated by the results in Table 4, where $69.44 \%$ of men and $87.50 \%$ of women consider the activity to be clearly beneficial to their lives, $30.56 \%$ of men and $12.50 \%$ of women are inclined towards a positive influence. Taking into account the age aspect, the results show that there are no significant differences between younger (under 35 years) and older respondents (over 35 years). $77.78 \%$ of younger respondents and $73.33 \%$ of older respondents expressed a clear "yes". It can be stated that in total $100 \%$ of the respondents, regardless of gender or age, expressed that they consider mono-skiing as a beneficial part of their life. The data showed that there was no significant difference in the assessment of the impact of mono-skiing on the quality of life between respondents older and younger in age or gender differentiated. Particularly for wheelchair users, who have severely limited opportunities for meaningful outdoor leisure activities, it may be one of the suitable options for active spending of their leisure time in winter. These findings are consistent with the results of the Ponti study [34], where it is documented that mono-skiing correlates with high levels of satisfaction, low levels of fear of falling and increased quality of life. Taking into account other thematically related publications, it can be concluded that mono-skiing is clearly recommended for sports therapy programs for these reasons. The results complement the opinion of Novosad [30], who understands quality of life with physical disability as a challenge on a personal and social level. An active individual with disability conceptualizes their current life situation as a challenge to overcome a difficult to unacceptable situation, and this can become a strong positive incentive to accept the disability. Time and effort devoted to an active lifestyle offers a wide range of impulses that have overlapping implications for quality of life. To understand in more detail how mono-skiing can help an individual with disability to improve their quality of life, it would be useful to complement the investigation with a qualitative part of the research in the form of case studies. The notion that for individuals with disability, 
physical activities are one of the important means of overall perception of life, its quality and value is illustrated by the results of our study.

The expressed preferences (Table 5) for the specific benefits of mono-skiing indicate the need for individuals with disability to seek a richer and more rewarding life. Three key benefits identified by survey respondents were the opportunity for fun and increased enjoyment of life $\left(X_{60}=50\right)$, feelings of excitement accompanying mono-skiing and thus enriching their own life $\left(\mathrm{X}_{60}=36\right)$, and the opportunity for building warm relationships with others while practicing it $\left(\mathrm{X}_{60}=30\right)$. This is consistent with the findings of de Groot et al. [7], who demonstrate the specific role and need for interaction with others in the physical activity of individuals with disability. Comparing these preferences with the findings of Hlaváčová's [12] survey suggests a possible social shift in the values sought. Selfrealization ranked significantly lower in our survey. Our results showed that the opportunity for selfrealization, as well as a sense of belonging or a sense of achievement, is considered less important. Slightly surprising, however, is the ranking of concern for one's own independence only in the second half of preferences. At the very end, respondents placed self-esteem and being respected by others. These facts may suggest that values in both majority and minority societies may change over time. Individuals with disability no longer consider it important to be favoured or do not care about pity from others. Therefore, they may not currently consider these values as important as an emotionally varied and rich life. This is consistent with Šimek's [39] view that contemporary people live primarily in the present, do not place emphasis on morality, and their lives are often dominated by a focus on powerful experiences.

\section{CONCLUSION AND IMPLICATIONS}

This survey analyses the experiences of individuals with disability with selected aspects related to mono-skiing. The findings help to evaluate mono-skiing in the diverse, non-homogeneous areas expressed in the study questions formulated. The results of our investigation show that mono-skiing clearly has a positive impact on individuals with physical disability. The main reasons for being active on the mono-ski included the joy of exercise, the opportunity to meet people and to contribute to their own mental well-being and improve their psyche. The vast majority of respondents consider mono-skiing to be a very essential part of their lives. The results of the study also show that a significant majority of the target group of people after an injury return to skiing again thanks to the mono-ski which contributes to maintain the level of their previous life. All the study respondents fully expressed the fulfilment of personal expectations from mono-skiing, whether they were those who had not been involved in skiing at all in the past or respondents who had already had experience of skiing before the accident and had engaged in the activity in a new, alternative way (mono-ski) after the accident. The three key benefits of mono-ski activity were cited by respondents as increased enjoyment of life and the opportunity to have fun, making life more varied and feeling excited, and establishing warm relationships with others.

These results and conclusions are the initial outputs of a larger study that will aim to evaluate the impact of mono-skiing on the quality of life in individuals with physical disability involved in this activity. The presented analysis of the experiences of individuals with disability with selected aspects related to mono-skiing may help to better evaluate the benefits of the activity for individuals with disability not only in terms of the possibility of realizing their own physical activity, but also for improving mental health, contact with others and resuming their favourite physical activity in the post-injury state.

\section{References}

[1] CHL - Centrum handicapovaných lyžařů Janské Lázně (2018). [Online]. Retrieved august 11, 2018 from http://monoski.info/ 
[2] Čapková, M. (2007). Význam sportu v životě osob se zdravotním postižením. České Budějovice: Jihočeská univerzita, Zdravotně sociální fakulta, katedra klinických oborů, časopis Kontakt. [Online]. Retrieved May 11, 2021 from http://casopiszsfju.zsf.jcu.cz/kontakt/administrace/clankyfile/20120327101923635778.pdf

[3] Coakley, J. \& Dunning, E. ed. (2003). Handbook of Sports Studies. London: Sage.

[4] Ditor D.S. et al. (2003). Maintenance of exercise participation in individuals with spinal cord injury: effects on quality of life, stress and pain. Spinal Cord; 41: pp. 446-50.

[5] Disman, M. (2011). Jak se vyrábí sociologická znalost. Praha: Karolinum.

[6] de Groot, S. et al. (2011). Is manual wheelchair satisfaction related to active lifestyle and participation in people with a spinal cord injury? J Spinal Cord; 49(4): pp. 560-65.

[7] de Groot, S. et al. (2020). Sport participation after the HandbikeBattle: benefits, barriers, facilitators from the event-a follow-up survey. J Spinal Cord Ser Cases; 6(1):54.

[8] Dušek, M. (2018). Závěrečná zpráva pro rok 2017/2018. [Online]. Retrieved March 2, 2021 from https://www.czechski.com/userfiles/files/KHL/ZZ/Zaverecna\%20zprava\%202017-2018.pdf

[9] Florio, J. et al. (2015). Need and use of assistive devices for personal mobility by individuals with spinal cord injury. J Spinal Cord Med, 39(4): pp. 461-70.

[10] Hardman, A. E., \& Stensel, D. J. (2009). Physical Aktivity and Health. New York.

[11] Hicks A. L. et al. (2011). The effects of exercise training on physical capacity, strength, body composition and functional performance among adults with spinal cord injury: a systematic review. Spinal Cord; 49: pp. 1103-27.

[12] Hlaváčková, P. (2006). Sport jako prostředek integrace lidí s tělesným handicapem do společnosti. [Bakalářská práce]. Praha: Evangelická teologická fakulta.

[13] Holm, N. J., Møller, T., Adamsen, L., Dalsgaard, L. T., Biering-Sorensen, F. \& Schou, L. H. (2019). Health promotion and cardiovascular risk reduction in people with spinal cord injury: physical activity, healthy diet and maintenance after discharge- protocol for a prospective national cohort study and a preintervention- postintervention study. BMJ Open; 9(12): e030310.

[14] Hruša, J. et al. (1999). Lyžování zdravotně postižených: Česká škola lyžování. Praha: Svaz lyžařů České republiky.

[15] Cho, H. S. et al. (2015). Comfort Analysis of Mono-ski with Hydraulic Absorber. Transactions of the KSME C Industrial Technology and Innovation; 3(2): pp. 131-40.

[16] IPC (2018). International Paralympic Committee: Wheelchair curling. [Online]. Retrieved March 11, 2021 from https://www.paralympic.org/wheelchair-curling

[17] Jacobs P. L., Nash M. L. \& Rusinowski J. W. (2001). Circuit training provides cardiorespiratory and strength benefits in persons with paraplegia. Med Sci Sports Exerc. 33; pp. 711-17.

[18] Jesenský, J. (2003). Zdravotně postižení - programy pro 21. století. Hradec Králové: Gaudeamus.

[19] Kábele, J. (1992). Sport vozíčkářů. Praha: Olympia.

[20] Kučera, M. \& Bartoňová, R. (2013). Dny na monoski 2013 - Příklad propagace APA pro širokou veřejnost. Studia Sportiva, 3, pp. 177-84.

[21] Kudláček, M. (2012). Organizace sportu s tělesným postižením. In Janeček, Z. et al. Vybrané kapitoly ze sportu osob se zdravotni postižením. Olomouc: Univerzita Palackého.

[22] Kudláček, M. \& Ješina, O. (2013). Integrovaná tělesná výchova. Olomouc: Univerzita Palackého. 
[23] Kvasnička, J. (2012). Metodika výuka lyžování na mono-ski. Olomouc: Univerzita Palackého.

[24] Lahtinen, U., Rantala, P. \& Malin, A. (2007). Physical performance of individuals With Intellectual Disability: A 30-Year Follow-Up. Adapted physical activity quarterly, 24, pp. 125-43.

[25] Langelier, E. et al. (2013). A sit-ski design aimed at controlling centre of mass and inertia. J Sports Sci; 31(10): pp. 1064-73.

[26] Martin, J. J. (2013). Benefits and barriers to physical activity for individuals with disabilities: a socialrelational model of disability perspective. Disabil Rehabil; 35(24): pp. 2030-37.

[27] Maslow, A., H. (2014). O psychologii bytí. Praha: Portál.

[28] Nasuti, G. \& Temple V. A. (2010). The risks and benefits of snow sports for people with disabilities: a review of the literature. Int J Rehabil Res; 33(3): pp. 193-98.

[29] Nixon, H. L. (2003) Sport and Health: Sport and Disability. In Coakley, J. and E. Dunning ed. Handbook of Sports Studies. London: Sage, pp. 432-38.

[30] Novosad, L. (2011). Tělesné postižení jako fenomén i životní realita: diskurzivní pohledy na tělo, tělesnost, pohyb, člověka a tělesné postižení. Praha: Portál.

[31] Opatřilová, D. \& Zámečníková, D. (2007). Somatopedie: Texty k distančnímu vzdělávání. Brno: Paido.

[32] Pavlasová, Š. (2019). Využití zimních sportovních aktivit pro osoby se zdravotním postižením. [Diplomová práce]. Hradec Králové: PdF UHK.

[33] Petrofsky, J., Meyer, J., Magsino, R., Zook, S., Kao, J. K. \& Magsino, R. et al. (2003). Biomechanics in physically disabled monoskiers versus conventional downhill skiers and snowboarders. J Appl Res; 3: pp. 124-36.

[34] Ponti, A. et al. (2020). Quality of life, concern of falling and satisfaction of the sit-ski aid in sit-skiers with spinal cord injury: observational study. Spinal Cord Ser Cases; 7; 6(1):8.

[35] Růžičková, K. \& Růžička, I. (2011). Development of social competences in youths with a visual impairment. Annales Universitatis Paedagogicae Cracoviensis - Studia Psychologica IV. Kraków: Wydawnictwo Naukowe UP, pp. 64-70.

[36] Sale, P., Mazzarella, F., Pagliacci, M. C., Aito, S., Agosti, M., Franceschini, M. (2012). Sport, free time and hobbies in people with spinal cord injury. Spinal Cord; 50: pp. 452-56.

[37] Slepička, P. et al. (2009). Psychologie sportu. Praha: Karolinum.

[38] Shapiro, R. D. \& Ulrich, A. D. (2001). Social Comparisons of Children With and Without Learning Disabilities When Evaluating Physical Competence. Adapted physical activity quarterly, 18, pp. 273-88.

[39] Šimek, J. (2015). Lékařská etika. Praha: Grada.

[40] Tweedy, S.M. (2016). Exercise and sports science Australia (ESSA) position statement on exercise and spinal cord injury. $J$ of Science and Medicine in Sport, volume 20, issue 2, pp. 108-15.

[41] van Koppenhagen, C. F. et al. (2014). Longitudinal relationship between wheelchair exercise capacity and life satisfaction in patients with spinal cord injury: A cohort study in the Netherlands. J Spinal Cord Med; 37(3): pp. 328-37.

[42] van Straaten M.G. et al. (2014). Effectiveness of home exercise on pain, function, and strength of manual wheelchair users with spinal cord injury: a high-dose shoulder program with telerehabilitation. Arch Phys Med Rehabil; 95 (e1812); pp. 1810-17.

[43] Vágnerová, M. (2004). Psychopatologie pro pomáhající profese. Praha: Portál. 
[44] Vágnerová, M. (2012). Vývojová psychologie. Praha: Portál.

[45] Waddington, I. (2003). Sport and Health: Sociological perspectives. In Coakley, J. and E. Dunning ed. Handbook of Sports Studies. London: Sage, pp. 408-21.

[46] WHO (2006). Promoting Physical activities and Active Living in Urban Environments. Geneva: Author.

[47] Williams, T. R., Smith, B. \& Papathomas, A. (2018). Physical activity promotion for people with spinal cord injury: Physiotherapists' beliefs and actions. Disability and Rehabilitation, 40, pp. 52-61. 